\title{
Relative importance of macrofaunal burrows for the microbial mineralization of pyrene in marine sediments: impact of macrofaunal species and organic matter quality
}

\author{
Maria E. Granberg ${ }^{1, *}$, Rikke Hansen ${ }^{2}$, Henriette Selck ${ }^{2}$ \\ ${ }^{1}$ Göteborg University, Department of Marine Ecology, Kristineberg Marine Research Station, 45034 Fiskebäckskil, Sweden \\ ${ }^{2}$ Department of Life Sciences and Chemistry, Roskilde University, 4000 Roskilde, Denmark
}

\begin{abstract}
The significance of macrofaunal burrows for microbial organic matter mineralization is well recognized. However, despite the importance of marine sediments as main sinks for organic particle-reactive contaminants such as polyaromatic hydrocarbons (PAHs), the significance of biogenic structures for microbial pollutant mineralization is largely unknown. We measured microbial mineralization of the PAH pyrene in different sediment compartments (surface, burrow and reduced bulk sediments) as a function of contamination history (uncontaminated and pyrene-exposed), macrofaunal species (Amphiura filiformis and Nereis diversicolor) and sediment organic matter quality (labile Tetraselmis sp. and refractory lignin). Sediments were exposed to combinations of the 3 factors for $43 \mathrm{~d}$, after which sediment samples from the 3 compartments were incubated for radio-respirometric measurements in ${ }^{14} \mathrm{C}$-pyrene-coated flasks to monitor ${ }^{14} \mathrm{CO}_{2}$ production (i.e. pyrene mineralization) for $128 \mathrm{~d}$. Pyrene exposure enhanced microbial pyrene mineralization (MPM) rates by an order of magnitude in all compartments, signifying MPM as inducible. MPM rates increased successively from reduced bulk to burrow and surface sediments in uncontaminated treatments, while MPM rates were highest in burrows when exposed to pyrene. This emphasizes the oxygen dependence of MPM and pinpoints burrows as MPM hot spots. Enrichment with labile organic matter doubled MPM rates in pyrene-exposed surface sediment, likely fertilizing MPM where oxygen is readily available. Burrow sediment MPM rates were doubled with A. filiformis, suggesting species-specific stimulation of the microbial community within the burrows. In conclusion, burrow sediment appears to be at least as important as surface sediment for microbial PAH degradation in marine sediments. Furthermore, macrofaunal biodiversity, sedimentation events and the trophic state of the system should be taken into account when the fate and effects of organic contaminants are assessed in marine systems.
\end{abstract}

KEY WORDS: Polyaromatic hydrocarbon · PAH · Biogenic structures · Biodegradation · Nereis diversicolor · Amphiura filiformis · Organic carbon quality

\section{INTRODUCTION}

Marine sediments constitute important sinks in the cycling of particle-reactive, persistent organic contaminants released into our biosphere. While point sources are being regulated, marine sediments storing old discharges have become major sources, accounting for contaminant effects propagating along food chains (Landrum \& Robbins 1990, Burgess \& Scott 1992). A thorough understanding of ecological processes in marine sediments is, therefore, fundamental for the prediction of contaminant fate and effects on many trophic levels. Polyaromatic hydrocarbons (PAHs) are a group of contaminants which are continuously 
released into our environment. Pyrene is a 4-ringed high molecular weight PAH of pyrogenic origin and, together with fluoranthene, benzo(b)fluoranthene and benzo(e)pyrene, it is the most abundant of the PAHs found in estuarine and marine sediments (HELCOM 1996, OSPAR-Commission 2000). In contrast to many other organic contaminants, PAHs are more readily degraded by most organisms but to a greatly varying and fairly unexplored extent (Cerniglia \& Heitkamp 1989, McElroy et al. 1989). Unfortunately, PAH metabolites may display higher toxicity than parent compounds, and due to their chronic release, acute toxicity, mutagenicity and carcinogenicity, PAHs are a contaminant group evoking high environmental concern (Jerina \& Daly 1974, OSPAR-Commission 2000).

Microbial degradation is considered the primary process leading to general $\mathrm{PAH}$ decontamination in both sediment and soil (Cerniglia \& Heitkamp 1989, Neff 2002). Degradation of PAHs has generally been proven more efficient under oxic conditions as the microbes involved are dependent on molecular oxygen for the initial enzymatic attack of the aromatic rings (Atlas 1981, Cerniglia 1992). Consequently, the highest sedimentary microbial PAH degradation rates have been detected in oxic surface layers (Gardner et al. 1979, Cerniglia \& Heitkamp 1989, Kure \& Forbes 1997). Repeated PAH exposure has also been proven to enhance microbial PAH degradation rates as well as the number of hydrocarbon-utilizing micro-organisms both in laboratory and field studies (Atlas 1981 and references therein, Bauer \& Capone 1985, Cerniglia \& Heitkamp 1989).

Sediment-dwelling macrofauna transform sediment into a structural and functional 3-dimensional medium. By constructing burrows and tubes, they extend the sediment water interface, thereby increasing the likely contact between sediment and oxygenated water. Around active biogenic structures (i.e. burrows and tubes), the sediment displays a significantly different biogeochemistry compared to the surrounding bulk sediment (Aller \& Yingst 1978, Forster 1996). Rapidly changing fluid dynamics and oxygen conditions, caused by intermittent speciesspecific macrofaunal irrigation, create burrow linings with steep chemical gradients and short diffusive distances, strongly favoring a great diversity of microbes (Aller 1994, Hulthe et al. 1998). Inhabited macrofaunal tubes and burrows may, thus, enhance the microbial degradation capacity of the deeper sediments by displaying surface-like interface properties (Aller 1988, Fenchel 1996, Kristensen 2000). The general stimulating effect of bioturbation on the oxygenation of deeper anoxic or reduced sediment, microbial activity and mineralization of organic matter is well documented (Aller \& Yingst 1985, Kristensen \& Black- burn 1987, Andersen \& Kristensen 1991). However, bioturbation also affects the general whole sediment distribution, release and microbial degradation of sediment-associated organic contaminants (Lee II \& Swartz 1980, Holmer et al. 1997, Kure \& Forbes 1997 , Gunnarsson et al. 1999a,b). The intensity of the macrofaunal impact on biogeochemical processes has, however, been shown to be highly species-specific and particularly attributed to differences in macrofaunal behavior (Aller \& Yingst 1985, Andersen \& Kristensen 1991). Since most studies apply whole sediment or 2-compartment models when studying contaminant fate, the relative importance of macrofaunal burrows, compared to surface and bulk sediments, for the microbial degradation of PAHs and other contaminants in marine sediment is yet highly unexplored with, to our knowledge, only 2 published studies (Chung \& King 1999, 2001).

Estimating contaminant fate in marine sediments is further complicated when organic matter input and sedimentation events are considered. The supply of organic matter to the sediment fuels the benthos, and changes seasonally both in terms of quantity and quality (Smetacek 1980, Gremare et al. 1997). Consequently, properties of sedimenting organic matter directly affect overall microbial metabolic activity, but may also indirectly affect microbes through changes in macrofaunal activity (Graf et al. 1983, Christensen \& Kanneworff 1985, 1986, Graf 1992), with anticipated consequences for the degradation of organic contaminants. Changes in sediment organic matter (SOM) quality may also influence microbial PAH degradation by affecting sedimentary oxygen conditions, and through altered bioavailability of sediment-associated contaminants (Xing 1997, Lueking et al. 2000).

In the present study, we experimentally investigated the relative capacity for microbial pyrene mineralization (MPM) in different compartments of the sediment, i.e. surface, burrow and reduced/anoxic bulk sediments. The aim was further to explore effects of macrofaunal species, SOM quality and pyrene-exposure history on the MPM rates. Macrofauna were represented by the semi-stationary suspension- and surfacedeposit feeding brittle star Amphiura filiformis (Echinodermata:Ophiuroidea), and the mobile omnivorous and predacious common ragworm Nereis diversicolor (Annelida:Polychaeta). SOM quality was manipulated by enriching sediment with low quality (refractory) terrestrial lignin or high quality (labile) microalgae (Tetraselmis sp.). The choice of substrates was based on a definition of reactive, labile high quality organic matter which, in line with Tenore (1977) and Gunnarsson et al. (1999a), refers to a substrate high in nitrogen and available amino acids and low in condensed structural hydrocarbons. 


\section{MATERIALS AND METHODS}

The study was conducted in 2 steps including an initial exposure phase followed by an incubation phase (Fig. 1). During the exposure phase, sediments were presented with specific treatments. The treatments were constructed as combinations of enrichments with either lignin or Tetraselmis sp. together with addition of Amphiura filiformis, Nereis diversicolor or no fauna. Double treatment sets were prepared in order to keep 1 set uncontaminated, while pyrene was added to the sediment in the other set. The resulting exposure treatment combinations are displayed in Table 1. At termination of the $43 \mathrm{~d}$ exposure phase, samples were collected from surface, burrow and bulk sediments. Sediment samples were transferred to individual radio-respirometric incubation flasks coated on the inside with radioactively-labelled pyrene $\left({ }^{14} \mathrm{C}\right.$-pyrene) . During a $128 \mathrm{~d}$ incubation period, radioactive carbon dioxide $\left({ }^{14} \mathrm{CO}_{2}\right)$ produced during microbial mineralization of ${ }^{14} \mathrm{C}$-pyrene was continuously collected in $\mathrm{NaOH}$-filled $\mathrm{CO}_{2}$ traps (Reid et al. 2001), with subsequent quantification using liquid scintillation counting. The system enabled us to compare the impact of the different exposure treatments on microbial pyrenemineralization potential in the different sediment compartments.

Collection of sediment and organisms. Sediment and brittle stars Amphiura filiformis were collected in March 2000 from $40 \mathrm{~m}$ depth north-west of the Gullmarsfjord $\left(58^{\circ} 20^{\prime} 30^{\prime \prime}, 11^{\circ} 21^{\prime} 60^{\prime \prime}\right)$ on the Swedish west coast using a $0.062 \mathrm{~m}^{2}$ box corer (Jonasson \& Olausson 1966). On deck, the upper oxidized sediment layer containing most of the macrofauna was removed from the lower reduced bulk sediment, separating the sediment from each core into 2 pools. In the lab, the bulk sediment was stored without sieving under reducing conditions (covered with a thin layer of $\mathrm{N}_{2}$-saturated water and a thick plastic film) in the dark at $5^{\circ} \mathrm{C}$ until use. Brittle stars $A$. filiformis were carefully collected from the oxidized sediment and were kept on a $1 \mathrm{~cm}$ layer of sieved (1 mm mesh size) surface sediment in tanks with continuous water flow ( $32 \mathrm{psu}$, $\left.5^{\circ} \mathrm{C}\right)$ until use. Polychaetes Nereis diversicolor were collected in April 2000 on a muddy sand flat on the shore of the Gullmarsfjord by digging. The worms were kept in flow-through aquaria $\left(32 \mathrm{psu}, 5^{\circ} \mathrm{C}\right)$ with a $5 \mathrm{~cm}$ layer of sieved surface sediment $(1 \mathrm{~mm}$ mesh size) until use. Additional oxidized surface sediment was collected in April 2000 from the same location as previously (northwest of the Gullmarsfjord); it was sieved
(1 $\mathrm{mm}$ mesh size) and stored with continuous flow $\left(32 \mathrm{psu}, 5^{\circ} \mathrm{C}\right.$ ) until use. One month prior to the experiment, thirty $1 \mathrm{l}$ wide-mouth glass jars were filled with $\sim 600 \mathrm{~g}$ wet wt (WW) homogenized reduced bulk sediment. The jars were covered with parafilm, lidded and placed in the same water bath $\left(5^{\circ} \mathrm{C}\right)$ in a dark constant temperature room $\left(5^{\circ} \mathrm{C}\right)$, allowing for microbial community adaptation to prevailing oxygen conditions.

Sediment preparation. The 2 carbon sources used for enrichment of the surface sediment layer were terrestrial lignin (Curan 100, Holmen paper AB) and a microalgae concentrate consisting of intact non-living cells of the chlorophyte Tetraselmis sp. (Reed Mariculture). Lignin is considered a low-quality, refractory carbon source, microbially low reactive, unpalatable to marine detrivorous macrofauna (e.g. Tenore et al. 1982, Gunnarsson et al. 1999a). Tetraselmis sp. has a high lipid and amino acid content (http://www.instantalgae.com/microalgae/tetraselmis.htm), and compared to lignin, it is much higher in total nitrogen (TN), and enriches the sediment content of total amino acids (TAA) and enzymatically hydrolyzable amino acids (EHAA) to a greater extent (Table 2). Consequently, Tetraselmis sp. is considered a labile, high-quality carbon source, microbially reactive and highly palatable to marine macrofauna. Equal amounts of total organic carbon (TOC) of the 2 carbon sources were added to the sediment. The TOC content of the sediment was increased from $\sim 2 \%$ dry wt (DW) sediment (Table 2 ) to $3 \%$ DW sediment by addition of $18 \mathrm{~g} \mathrm{WW}$ of Tetraselmis sp. and $5.9 \mathrm{~g} \mathrm{DW}$ of lignin per $\mathrm{kg}$ WW of sieved (1 mm mesh size) and homogenized oxidized surface sediment. This resulted in a TN content 24 times higher in the sediment enriched with Tetraselmis

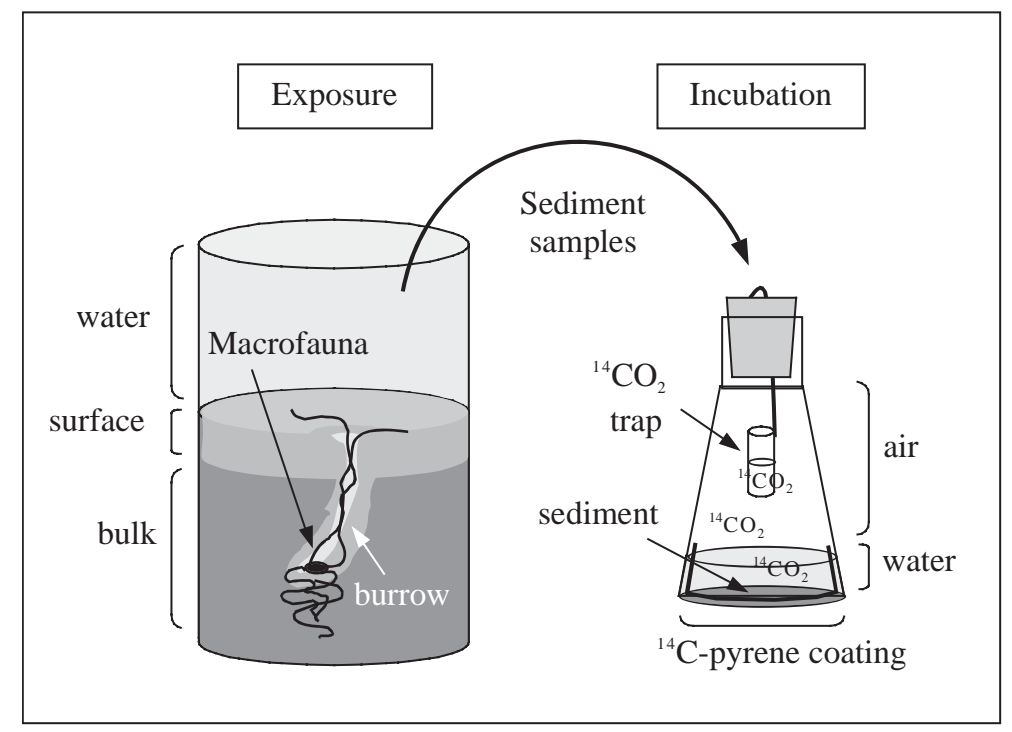

Fig. 1. Schematic diagram of the experimental design including exposure and incubation phases 
Table 1. Exposure phase treatments. X: indicates an existing combination; -: indicates absence of the combination, $\mathrm{n}=3$

\begin{tabular}{|lcccc|} 
& \multicolumn{3}{c}{ Uncontaminated } & \multicolumn{2}{c|}{ Pyrene-exposed } \\
& \multicolumn{1}{c}{ Tetraselmis sp. } & Lignin & Tetraselmis sp. & Lignin \\
\hline No fauna & - & - & $\mathrm{X}$ & $\mathrm{X}$ \\
Amphiura filiformis & $\mathrm{X}$ & $\mathrm{X}$ & $\mathrm{X}$ & $\mathrm{X}$ \\
Nereis diversicolor & $\mathrm{X}$ & $\mathrm{X}$ & $\mathrm{X}$ & $\mathrm{X}$ \\
\hline
\end{tabular}

was counted using duplicate cuvettes (excitation: $340 \mathrm{~nm}$; emission: $455 \mathrm{~nm}$ ). EHAA samples were subtracted for protease blanks. Amino acid concentrations were determined by calibrating the fluorescence to a diluted solution of amino acid standard (Sigma AA-S-18) at $0.5,1.0,2.5$ and $5.0 \mathrm{nmol}$ $\mathrm{ml}^{-1}$.

Contaminated and uncontaminated sp. (156 mg kg WW-1 sediment) compared to the lignin-enriched sediment (6.5 $\mathrm{mg} \mathrm{kg} \mathrm{WW}^{-1}$ sediment). A small amount of seawater was added to the sediment in order to make it less cohesive for a more homogenous mixing of the organic matter; this was accounted for in the calculations. After enrichment, the sediments were agitated for $24 \mathrm{~h}$ on a shaking table at $5^{\circ} \mathrm{C}$ in darkness. Contents of total carbon (TC) and TN in sediment and organic substrates were measured on freeze-dried samples with a Carlo Erba elemental analyzer (NA 1500 NC, Fisons Instruments). TOC was determined accordingly after treating samples with $\mathrm{HCl}$ to remove carbonates (Hedges \& Stern 1984). TAA and EHAA were also analyzed on freeze-dried sediment samples according to the method of Mayer et al. (1995). The sedimentary EHAA contents representing the amount of amino acids available to deposit-feeders, were analyzed by incubating $100 \mathrm{mg}$ of dry sediment with proteolytic enzymes (Proteinase K, Sigma P-8044) in a shaking incubator in the dark at $37^{\circ} \mathrm{C}$ for $6 \mathrm{~h}$, followed by precipitation of non-digested proteins with trichloro-acetic acid. The supernatant, containing digested peptides and amino acids, was then hydrolyzed in $\mathrm{HCl}(6 \mathrm{~N})$ under $\mathrm{N}_{2}$ for $24 \mathrm{~h}$ at $110^{\circ} \mathrm{C}$. The samples were neutralized in a $\mathrm{pH} 8$ boric acid buffer, stained with 0-phthaldialdehyde (OPA) (Sigma P-8044) and fluorescence was measured with a Hitachi F-4500 fluoresence spectrophotometer. Sedimentary TAA contents were analyzed by $24 \mathrm{~h}$ acid hydrolysis $(6 \mathrm{~N} \mathrm{HCl})$ of $50 \mathrm{mg}$ of dry sediment followed by neutralization, staining with OPA and fluorescence measurement. All samples were extracted in triplicates, and fluorescence surface exposure sediments were prepared for both carbon sources in acetone-rinsed glass jars (3 1), by adding a known volume of pyrene (contaminated) (3.1 mg chrystalline pyrene $\mathrm{ml}^{-1}$ acetone, purity $>98 \%$, Sigma-Aldrich) or a corresponding volume of acetone (uncontaminated) to respective jars. The jars were agitated in darkness allowing for the solvent to evaporate $(\sim 4 \mathrm{~h})$. A known amount of the organically-enriched wet sediment was added to the prepared glass jars, producing a pyrene/acetone and acetone-only spiked set for each carbon source. The jars were left for another $24 \mathrm{~h}$ on the shaking table in darkness allowing for the contaminant to bind and mix with the sediment reaching a final nominal concentration of $30 \mu \mathrm{g}$ pyrene g DW ${ }^{-1}$ sediment.

Exposure phase. One hundred $\mathrm{g}$ WW of the prepared surface sediment was added to each of the 30 jars (1 l, diameter: $10 \mathrm{~cm}$, height: $15 \mathrm{~cm}$ ) on top of the bulk sediment. Each jar finally contained reduced bulk sediment ( $6 \mathrm{~cm}$ deep) covered by a layer $(\sim 2 \mathrm{~cm})$ of organically-enriched (with lignin or Tetraselmis sp.) and pyrene-contaminated (18 jars) or uncontaminated (12 jars) oxidized surface sediment with a surface area of $0.008 \mathrm{~m}^{2}$. The jars were sealed with lids perforated for in- and out-flowing water and were then carefully filled with seawater $\left(32 \mathrm{psu}, 5^{\circ} \mathrm{C}\right)$ preventing resuspension. The jars were placed in random order in a large water bath $\left(5^{\circ} \mathrm{C}\right)$ in a dark climate room $\left(5^{\circ} \mathrm{C}\right)$, individually connected to a continuous flow of fresh seawater (32 $\mathrm{psu}, 5^{\circ} \mathrm{C}$ ) of $40 \mathrm{ml} \mathrm{min}{ }^{-1}$, giving a water residence time of $13 \mathrm{~min}$. After connection to the flow, the jars were left to stabilize for $24 \mathrm{~h}$ before the addition of ani-

Table 2. Initial specifications of sediment and organic carbon sources. TN: total nitrogen; TC: total carbon; TOC: total organic carbon. TAA (total amino acids) and EHAA (enzymatically hydrolyzable amino acids) both measured on initial sediment enriched with respective organic carbon source. DW: dry wt of organic carbon source or sediment; -: not analyzed. Means of 3 replicates $( \pm \mathrm{SD})$ are shown

\begin{tabular}{|c|c|c|c|c|c|}
\hline Source & $\begin{array}{c}\text { TN } \\
(\% \mathrm{DW})\end{array}$ & $\begin{array}{c}\mathrm{TC} \\
(\% \mathrm{DW})\end{array}$ & $\begin{array}{c}\text { TOC } \\
(\% \text { DW })\end{array}$ & $\begin{array}{c}\text { TAA } \\
\left(\mu_{\text {mol g DW }}{ }^{-1}\right)\end{array}$ & $\begin{array}{c}\text { EHAA } \\
\left(\mu \mathrm{mol} \mathrm{g} \mathrm{DW} \text { sed }^{-1}\right)\end{array}$ \\
\hline Sediment & $0.33 \pm 0.03$ & $4.25 \pm 0.15$ & $2.15 \pm 0.41$ & - & - \\
\hline Lignin & $0.11 \pm 0.004$ & $61.1 \pm 0.9$ & $52.5 \pm 2.9^{\mathrm{a}}$ & $699 \pm 51$ & $101 \pm 6$ \\
\hline $\begin{array}{l}\text { Tetraselmis sp. } \\
{ }^{\mathrm{a}} \mathrm{n}=2\end{array}$ & $1.88 \pm 0.13^{\mathrm{a}}$ & $37.7 \pm 0.7^{\mathrm{a}}$ & $37.5 \pm 1.0^{\mathrm{a}}$ & $799 \pm 40$ & $160 \pm 2$ \\
\hline
\end{tabular}


mals and initiation of the experiment. Brittle stars and ragworms were carefully sieved out from storage tank sediments. Seven Nereis diversicolor ( $7 \mathrm{~cm}$ in length) with a total biomass of $\sim 3 \mathrm{~g} \mathrm{WW}$ were added to each of 12 jars and 4 Amphiura filiformis (1 cm disk diameter) with a total biomass of $\sim 1 \mathrm{~g} \mathrm{WW}$ were added to each of another 12 jars. The total exposure period lasted for $43 \mathrm{~d}$ with continuous water flow at $5^{\circ} \mathrm{C}$ in darkness.

Incubation phase $\left({ }^{14} \mathbf{C O}_{2}\right.$ production). At the termination of the exposure phase, the jars were dismantled from the flow system, the water was carefully removed, and sediment samples were collected from the different compartments and transferred to separate polyethylene zip-lock bags. Surface and bulk sediment samples were collected with a stainless steel spoon rinsed between sampling in $96 \%$ EtOH. Amphiura filiformis burrows were sampled by extracting sediment with sterile disposable syringes and thick long needles (diameter: $2.1 \mathrm{~mm}$, length: $80 \mathrm{~mm}$ ). Only burrows visible through the glass walls were sampled and only sediment from the arm burrow linings, with a lighter color than the bulk sediment was collected. When collecting samples from Nereis diversicolor burrows, the entire sediment was forced out of the jar and carefully 'opened' in halves exposing the burrows. A stainless steel spoon with a very small bowl was used to scrape off the burrow linings. The spoon was rinsed in $96 \%$ EtOH between sampling. The sediment samples were carefully packed and shipped overnight in a refrigerated box $\left(\sim 6^{\circ} \mathrm{C}\right)$ to Roskilde University, Roskilde, Denmark. There, the samples were transferred to sterile $200 \mathrm{ml}$ Erlenmeyer flasks coated on the inside with $0.15 \mu \mathrm{Ci}\left(4,5,9,10-{ }^{14} \mathrm{C}\right)$ pyrene $\left(58.7 \mathrm{mCi} \mathrm{mmol}^{-1}\right.$, purity $>98 \%$, Sigma-Aldrich). Coating was accomplished by adding $100 \mu \mathrm{l}{ }^{14} \mathrm{C}$-pyrene dissolved in acetone $\left(1.5 \mu \mathrm{Ci} \mathrm{ml}^{-1}\right)$ to each flask, then allowing the acetone to evaporate. The sediment was covered with a thin layer of water ( $50 \mathrm{ml}, 32 \mathrm{psu}$ ) and the flasks, containing a large headspace of air, were sealed with silicone stoppers. Replicated ${ }^{14} \mathrm{C}$-pyrene-coated flasks filled with seawater only served as controls for the incubation-flask system (SW only controls). Traps for $\mathrm{CO}_{2}$, consisting of $6 \mathrm{ml}$ plastic scintillation vials, were fitted in the center of the flasks attached with steel wires to the silicone stoppers (Fig. 1). The vials were filled with $5 \mathrm{ml} 0.5 \mathrm{M} \mathrm{NaOH}$ trapping the ${ }^{14} \mathrm{CO}_{2}$ produced by microbes mineralizing the ${ }^{14} \mathrm{C}$-pyrene in the sediment. Incubations were run under oxic conditions at $10^{\circ} \mathrm{C}$ in darkness for a period of $128 \mathrm{~d}$, during which the $\mathrm{CO}_{2}$ traps were sampled on 12 occasions and flasks were simultaneously aerated. On each sampling occasion, $3 \mathrm{ml}$ of $\mathrm{NaOH}$ was collected and transferred to scintillation vials, $15 \mathrm{ml}$ scintillation liquid (Ecoscint A, National Diagnostics) was added and samples were left overnight, after which radioactivity was quantified by liquid scintillation counting (LSC) on a Wallac 1409 liquid scintillation system, with corrections made for quenching by the external-standards ratio method after background subtraction. After sample collection, trap vials were emptied and refilled with fresh $\mathrm{NaOH}$ $(5 \mathrm{ml}, 0.5 \mathrm{M})$. At the termination of the incubations, samples were collected from the sediment and overlying water, and plastic traps and glass walls were extracted in order to measure the remaining amount of radioactivity and make a budget for the dynamics of ${ }^{14} \mathrm{C}$-pyrene for the incubation systems.

Flask budget samples. Water samples from the incubation flasks were assayed for radioactivity in forms of ${ }^{14} \mathrm{CO}_{2}$, dissolved organic carbon $\left(\mathrm{DO}^{14} \mathrm{C}\right)$ and particulate organic carbon $\left(\mathrm{PO}^{14} \mathrm{C}\right)$. Three $\mathrm{ml}$ of the overlying water was collected with a syringe and needle, and dispensed into a glass scintillation vial through a glass fiber filter (GF75, pore size <0.7 $\mu \mathrm{m}$, Advantec, Frisenette $\mathrm{ApS}$ ). The GF filter collecting aqueous $\mathrm{PO}^{14} \mathrm{C}$ was dissolved with $1 \mathrm{ml}$ Soluene 350 (Packard) in a glass scintillation vial, $15 \mathrm{ml}$ of scintillation cocktail (Ultima Gold XR, Packard) was added and radioactivity was quantified by LSC. The vials containing the filtered water were sealed with silicone stoppers, each fitted with a $0.5 \mathrm{M} \mathrm{NaOH}$ soaked GF filter hooked onto a steel wire connected to the stopper. Three drops of $\mathrm{HCl}$ (fuming) were added to each water sample with a syringe by pushing the needle through the silicone stopper and gently dispensing the acid. To allow for complete release from water and uptake of ${ }^{14} \mathrm{CO}_{2}$ on filters, vials were placed on gentle agitation overnight at $10^{\circ} \mathrm{C}$ in darkness. Following incubation, filters were transferred to new scintillation vials, dissolved as above and prepared for quantification of ${ }^{14} \mathrm{CO}_{2}$ derived radioactivity. Ultima Gold XR (15 ml) was added to the remaining water samples to quantify $\mathrm{DO}^{14} \mathrm{C}$-derived radioactivity. The sediment was removed from the flasks, weighed and oven-dried in semi-enclosed aluminium cups at $105^{\circ} \mathrm{C}$ for $24 \mathrm{~h}$, left to cool and then reweighed. Samples of $0.1 \mathrm{~g}$ were collected from the dried sediment and transferred to scintillation vials. One $\mathrm{ml}$ of Soluene 350 was added, to each vial and the mixture was ultrasonicated for $10 \mathrm{~min}$. Ten $\mathrm{ml}$ of Ultima gold XR was added, and samples were left overnight then analyzed by LSC. To extract ${ }^{14} \mathrm{C}$-pyrene from the glass walls, the flasks were rinsed 3 times with $5 \mathrm{ml}$ acetone. The acetone was transferred to glass scintillation vials then left to evaporate before addition of $10 \mathrm{ml}$ Ultima gold XR followed by LSC. The plastic trap vials were placed in large scintillation vials, $18 \mathrm{ml}$ Ultima Gold XR was added and radioactivity was quantified by LSC.

Trapping efficiency. A test was conducted in order to investigate the trapping efficiency of ${ }^{14} \mathrm{CO}_{2}$ in the incubation flask systems. Three different quantities of sed- 
iment, corresponding to the sample weight variation in the main experiment, $(0.5,2$ and $4 \mathrm{~g}$ DW sediment, $\mathrm{n}=$ 4 ), were tested in order to control for possible effects of the amount of sediment on $\mathrm{CO}_{2}$ retention. Sediment was collected from the Gullmarsfjord as described previously; only the oxidized top sediment layer was sieved (1 $\mathrm{mm}$ mesh size), autoclaved in appropriate amounts in individual blue cap flasks and stored in darkness at $6^{\circ} \mathrm{C}$ until use. The sediment was mixed with $50 \mathrm{ml}$ of $0.3 \mu \mathrm{m}$ filtered and autoclaved seawater (32 psu, $5^{\circ} \mathrm{C}, \mathrm{pH} 8$ ) and decanted into $200 \mathrm{ml}$ Erlenmeyer flasks. A total of $900 \mu$ l of radioactive sodium carbonate $\left(\mathrm{NaH}^{14} \mathrm{CO}_{3}\right)$ dissolved in filtered and autoclaved seawater $\left(0.38 \mu \mathrm{Ci} \mathrm{ml}^{-1}\right)$ was added to the sediment slurries, and flasks were sealed and left in darkness at $6^{\circ} \mathrm{C}$ overnight for the sediment to settle. Four of the flasks containing $2 \mathrm{~g}$ DW sediment were sealed with silicone stoppers fitted with $\mathrm{CO}_{2}$ traps (as described above) in order to control for possible early breakdown of $\mathrm{NaH}^{14} \mathrm{CO}_{3}$. The following day, glass vials containing $1 \mathrm{ml}$ of concentrated $\mathrm{HCl}$ were carefully placed on the bottom of the remaining flasks. The flasks were resealed with silicone stoppers fitted with $\mathrm{CO}_{2}$ traps filled with $5 \mathrm{ml} 0.5 \mathrm{M} \mathrm{NaOH}$ as above. The $\mathrm{HCl}$-vials were then knocked over and $\mathrm{HCl}$ was released into the sediment and water, lowering the $\mathrm{pH}$ sufficiently $(\mathrm{pH}<2)$ for all of the $\mathrm{NaH}^{14} \mathrm{CO}_{3}$ to be converted into ${ }^{14} \mathrm{CO}_{2}$. The flasks were left in darkness at $10^{\circ} \mathrm{C}$ and sampled for ${ }^{14} \mathrm{CO}_{2}$ production after $2,4,8$ and $16 \mathrm{~d}$, when $3 \mathrm{ml}$ of $\mathrm{NaOH}$ was removed from the trapping vials and transferred to scintillation vials. Ten ml of Ultima Gold XR was added and samples were counted on a Beckman LS5000TD liquid scintillation system (Beckman instruments) and corrected for quench by the external-standards ratio method after background subtraction.

Calculations and statistical analyses. Radioactivity values (DPM) derived from the amounts of ${ }^{14} \mathrm{CO}_{2}$ trapped during the incubation were corrected for the weight of incubation flask sediment using an empirically derived formula from the extraction efficiency test - $\mathrm{f}(\mathrm{x})$ $=-4.95 x+97.4, \mathrm{r}^{2}=0.866, x=\mathrm{g}$ DW sediment and $\mathrm{f}(\mathrm{x})=$ ${ }^{14} \mathrm{CO}_{2}$-derived DPM - and were then normalized to dry weights of incubation flask sediments. Microbial pyrene-mineralization rates (MPM rates, $\mathrm{g} \mathrm{DW}_{\text {sed }}{ }^{-1} \mathrm{~d}^{-1}$ ) were calculated as DPM/(DPM $\left.M_{\text {initial }} \times d \times g D_{\text {sed }}\right)$ from the slopes of regressions calculated from weight-specific relative ${ }^{14} \mathrm{CO}_{2}$ production versus time graphs, using the 3 initial data points. Calculated slope values were logtransformed $\left(\log _{10}\right)$ before being statistically tested. Levene Median and Kolmogorov-Smirnov tests were used for verification of homogeneity of variances and normality of data sets, respectively. Among compartments (surface, burrow and bulk sediments), $\log _{10}$-transformed MPM rates were compared using 1-way ANOVAs, al- though with separate testing of uncontaminated and pyrene-exposed data sets. The factors carbon source (lignin or Tetraselmis sp.) and fauna (Amphiura filiformis, Nereis diversicolor or no fauna) were tested independently within each compartment using orthogonal 2-way ANOVAs, where pyrene-exposed and uncontaminated sets were again treated separately. Ranking among levels within significant factors were resolved by Tukey post hoc tests. Budgets and percentages were calculated on the basis of empirical DPM values obtained during the initial additions of ${ }^{14} \mathrm{C}$-pyrene.

\section{RESULTS}

Pyrene exposure induced the greatest overall treatment effect, resulting in increased microbial pyrenemineralization (MPM) rates in all compartments by approximately an order of magnitude (differences between uncontaminated and contaminated sediments; surface $10^{0.91}$, burrow $10^{1.37}$, anoxic $10^{1.30}$ ) (Fig. 2). The highest MPM rates among sediment compartments within each treatment were generally observed in surface sediment, while the lowest rates were found in bulk sediment (Table 3). Generally, MPM rates in burrow sediment were almost equal to surface sediment MPM rates. However, the highest MPM rates detected in the entire experiment were measured in pyrene-exposed, lignin-enriched sediment from burrows made by Amphiura filiformis (Table 3). The MPM rate interrelationship among compartments depended on whether or not sediments were exposed to pyrene (Fig. 2). In uncontaminated treatments, MPM rates increased successively from bulk to burrow and surface sediment (ANOVA $F_{2,33}=$

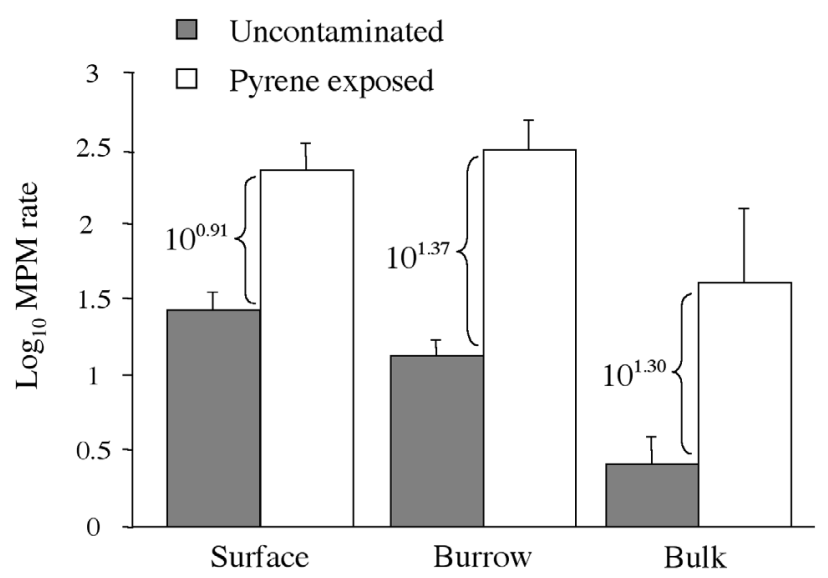

Fig. 2. Comparison of microbial pyrene-mineralization rates

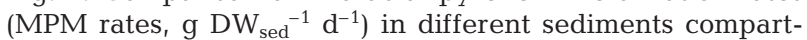
ments, i.e. surface, burrows, and bulk sediment either uncontaminated or exposed to pyrene. Faunal treatments are pooled. Error bars indicate $+\mathrm{SD}$ 
Table 3. Microbial ${ }^{14} \mathrm{CO}_{2}$ production rates $\left(10^{-3} \mathrm{~g} \mathrm{DW}_{\text {sed }}{ }^{-1} \mathrm{~d}^{-1}\right)$ per initially added ${ }^{14} \mathrm{C}$-pyrene in sediment from the different treatments and sediment compartments. Means of 3 replicates \pm SD are shown. -: no burrows present in treatments without fauna

\begin{tabular}{|c|c|c|c|c|}
\hline \multirow[t]{2}{*}{ Carbon source } & \multirow[t]{2}{*}{ Fauna } & \multicolumn{3}{|c|}{ Microbial ${ }^{14} \mathrm{CO}_{2}$ production rate $\left(10^{-3} \mathrm{~g} \mathrm{DW}_{\mathrm{sed}}{ }^{-1} \mathrm{~d}^{-1}\right)$} \\
\hline & & Surface & Burrow & Bulk \\
\hline \multicolumn{5}{|l|}{ Pyrene-exposed } \\
\hline Tetraselmis sp. & No fauna & $3.65 \pm 1.20$ & - & $0.23 \pm 0.30^{\mathrm{a}}$ \\
\hline Tetraselmis sp. & Amphiura filiformis & $3.37 \pm 0.23$ & $3.27 \pm 1.33^{\mathrm{a}}$ & $0.41 \pm 0.33$ \\
\hline Tetraselmis sp. & Nereis diversicolor & $2.38 \pm 0.28$ & $2.16 \pm 0.14$ & $0.83 \pm 0.17$ \\
\hline Lignin & No fauna & $1.63 \pm 0.50$ & - & $0.36 \pm 0.07^{a}$ \\
\hline Lignin & A. filiformis & $1.51 \pm 0.17$ & $5.74 \pm 2.45$ & $0.23 \pm 0.14$ \\
\hline Lignin & N. diversicolor & $1.72 \pm 0.27$ & $2.34 \pm 0.24$ & $1.50 \pm 0.78$ \\
\hline \multicolumn{5}{|l|}{ Uncontaminated } \\
\hline Tetraselmis sp. & A. filiformis & $0.30 \pm 0.12$ & $0.16 \pm 0.03^{\mathrm{a}}$ & $0.017 \pm 0.001$ \\
\hline Tetraselmis sp. & N. diversicolor & $0.27 \pm 0.02$ & $0.15 \pm 0.02$ & $0.029 \pm 0.002$ \\
\hline Lignin & A. filiformis & $0.24 \pm 0.03$ & $0.11 \pm 0.03^{\mathrm{a}}$ & $0.030 \pm 0.002$ \\
\hline Lignin & N. diversicolor & $0.28 \pm 0.08$ & $0.12 \pm 0.04$ & $0.033 \pm 0.02$ \\
\hline${ }^{\mathrm{a}} \mathrm{n}=2$ & & & & \\
\hline
\end{tabular}

178, $\mathrm{p}<0.001$; Tukey $\mathrm{p}<0.05$ for all pairwise comparisons). In pyrene-exposed treatments, burrow and surface sediment MPM rates were equally high, while significantly lower rates were observed in the bulk sediment (ANOVA $F_{2,33}=24.5, \mathrm{p}<0.001$; Tukey $\mathrm{p}<$ 0.05). The strong effect of pyrene exposure called for a separate treatment of pyrene-exposed and uncontaminated data sets in subsequent statistical comparisons.
Furthermore, MPM rates in seawater-only controls nearly equaled zero $\left(0.006 \times 10^{-3} \mathrm{~g} \mathrm{DW}_{\text {sed }^{-1}} \mathrm{~d}^{-1}\right)$ (Fig. 3A), indicating that the mineralization measured during the incubation phase almost exclusively originated from exposure sediments.

Visual observations confirmed an identical development of redox patterns (see Fig. 5) in pyrene-exposed and uncontaminated treatments. No difference was

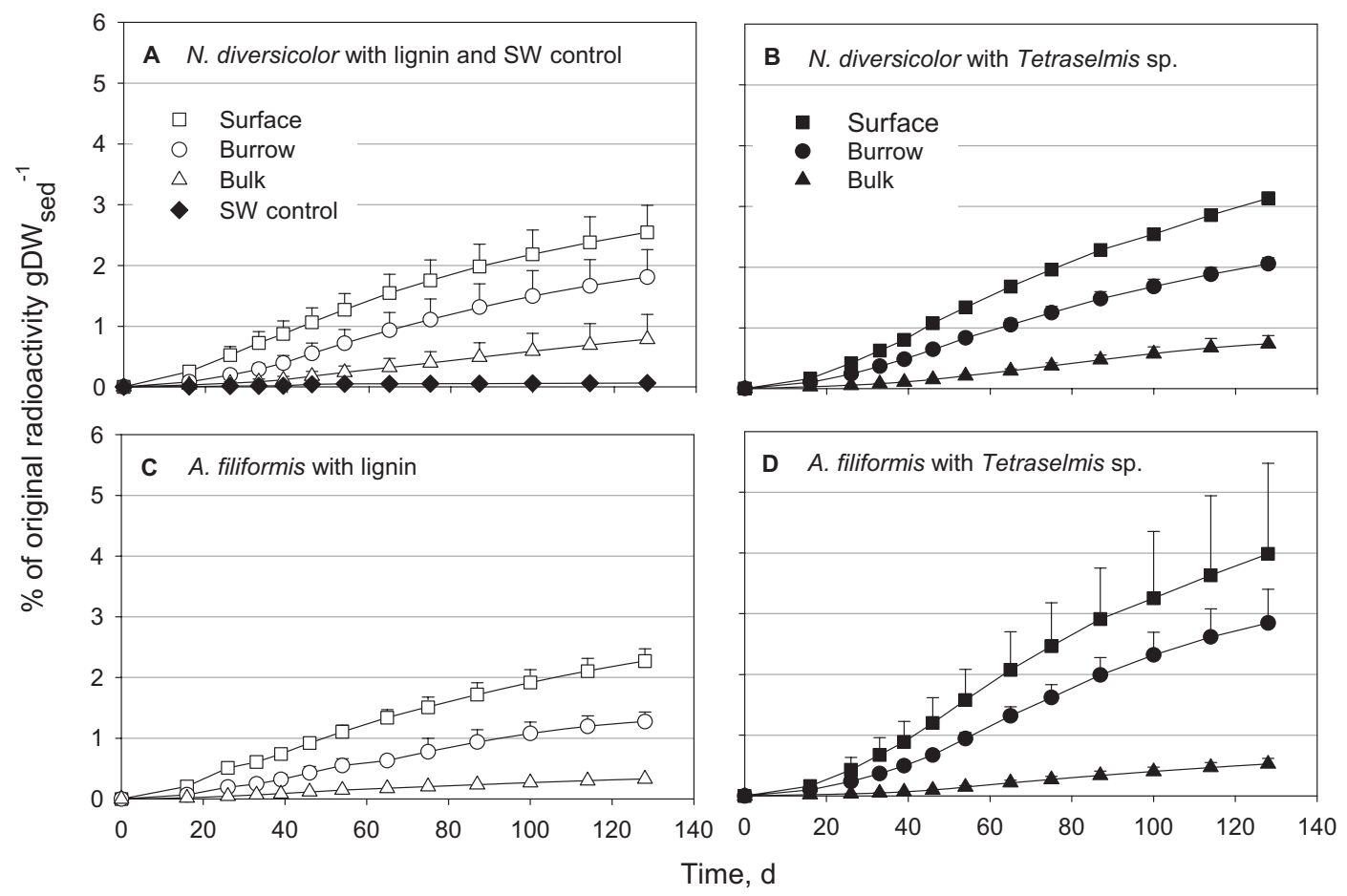

Fig. 3. Cumulative ${ }^{14} \mathrm{C}$-pyrene-derived microbial ${ }^{14} \mathrm{CO}_{2}$ production from incubations of uncontaminated surface, burrow and bulk sediments. ${ }^{14} \mathrm{CO}_{2}$ production is expressed as $\% \mathrm{~g} \mathrm{DW}_{\text {sed }}{ }^{-1}$, i.e. the isotopic activity of the produced ${ }^{14} \mathrm{C}$-pyrene-derived ${ }^{14} \mathrm{CO}_{2}$ divided by the isotopic activity of the ${ }^{14} \mathrm{C}$-pyrene originally added and the amount of sediment ( $\mathrm{g}$ DW) in each incubation flask.

Each point represents 3 replicates and error bars indicate $+\mathrm{SD}$ 
observed in macrofaunal behavior or mortality between uncontaminated and pyrene-exposed treatment. All brittle stars originally added to experimental jars were recovered at the end of the exposure phase, while single polychaete worms were lost, i.e. escaped from or died in single exposure phase jars.

\section{Surface sediment}

Microbial pyrene-mineralization rates ranged from $0.24 \times 10^{-3}$ to $0.30 \times 10^{-3} \mathrm{~g} \mathrm{DW}_{\text {sed }}^{-1} \mathrm{~d}^{-1}$ in uncontaminated surface sediment, with no effect of either fauna or organic matter quality (ANOVA $F_{1,8}=0.07$ and 0.27 , p >> 0.05) (Table 3). In pyrene-exposed sediment, organic matter quality had a significant effect on MPM rates, with higher mineralization rates measured in sediments enriched with Tetraselmis sp. than in sediment enriched with lignin (ANOVA $F_{1,12}=42.05$, $\mathrm{p}<0.001)$. The MPM rates ranged between $1.51 \times 10^{-3}$ g DW sed $^{-1} \mathrm{~d}^{-1}$ in sediment exposed to pyrene/lignin/ Amphiura filiformis, and $3.65 \times 10^{-3} \mathrm{~g} \mathrm{DW}_{\text {sed }}{ }^{-1} \mathrm{~d}^{-1}$ in sediment exposed to pyrene/Tetraselmis sp./no fauna (Table 3), and were independent of the presence of fauna or faunal species (ANOVA $F_{2,12}=0.804, \mathrm{p}>>$ 0.05).

\section{Burrow sediment}

Microbial pyrene-mineralization rates in uncontaminated burrow sediments were approximately half of the MPM rates measured in surface sediments within each treatment. There was a significant effect of organic matter quality, with higher MPM rates measured in sediments enriched with Tetraselmis sp. than in those enriched with lignin (ANOVA $F_{1,8}=6.95, \mathrm{p}=$ 0.03) (Table 3). There was no effect of macrofaunal species on the MPM rates in uncontaminated sediments (ANOVA $F_{1,8}=0.171, \mathrm{p}>>0.05$ ). When exposed to pyrene, however, burrow sediment MPM rates showed a significant effect of fauna (ANOVA $F_{1,8}=$ 12.24, $\mathrm{p}=0.008$ ) with MPM rates 1.5 to 2.5 times higher in Amphiura filiformis burrow sediment than in sediment from Nereis diversicolor burrows (Table 3 \& Fig. 4C-F). No effect was observed of organic matter quality (ANOVA $F_{1,8}=2.92, \mathrm{p}>>0.05$ ) in pyreneexposed burrow sediments. The highest MPM rates observed in the entire experiment were measured in pyrene-exposed sediment, enriched with lignin, from burrows made by $A$. filiformis (pyrene/lignin/A. filiformis) (Table 3, Fig. 4E). The average MPM rate in these burrows $\left(5.74 \times 10^{-3} \mathrm{~g} \mathrm{DW}_{\text {sed }}{ }^{-1} \mathrm{~d}^{-1}\right)$ was 3.8 times higher than the average rate measured in surface sediment $\left(1.51 \times 10^{-3} \mathrm{~g} \mathrm{DW}_{\text {sed }}^{-1} \mathrm{~d}^{-1}\right)$ within the same treat- ment. High MPM rates were further accompanied by greater variances (Table 3, Fig. 4E). The greater variance was a pattern more frequently observed in pyrene-exposed burrow sediment of $A$. filiformis than of $N$. diversicolor, and seemed independent of organic matter quality (Fig. 4C-F).

\section{Bulk sediment}

Microbial pyrene-mineralization rates in bulk sediment were generally an order of magnitude lower than MPM rates in surface and burrow sediments. Uncontaminated bulk sediment showed the lowest sedimentary MPM rates measured in the experiment, ranging

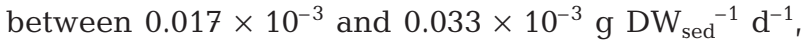
with no significant effect of either fauna or organic matter quality (ANOVA $F_{1,8}=1.3$ and 1.1, p >> 0.05) (Table 3, Fig. 3). Fauna was, however, the governing factor in pyrene-exposed sediment, with higher MPM rates measured in sediment with Nereis diversicolor compared to treatments with both Amphiura filiformis and no fauna (ANOVA $F_{2,12}=5.8, \mathrm{p}=0.017$, Tukey $\mathrm{p}<$ 0.05) (Table 3, Fig. 4). In fact, the highest average bulk sediment MPM rate measured in the experiment $(1.50$ $\times 10^{-3} \mathrm{~g} \mathrm{DW}_{\text {sed }}^{-1} \mathrm{~d}^{-1}$ ) occurred with $N$. diversicolor in pyrene-exposed, lignin-enriched sediment, almost equalling the average surface sediment MPM rate $\left(1.72 \times 10^{-3} \mathrm{~g} \mathrm{DW}_{\text {sed }}^{-1} \mathrm{~d}^{-1}\right)$ within the same treatment (Table 3, Fig. 4C).

\section{Flask budget}

The flask budget for added radioactivity was performed by extracting ${ }^{14} \mathrm{C}$-pyrene-derived radioactivity from the sediment, the water (as $\mathrm{PO}^{14} \mathrm{C}, \mathrm{DO}^{14} \mathrm{C}$ and ${ }^{14} \mathrm{CO}_{2}$ ), from glass walls, plastic traps, and as total ${ }^{14} \mathrm{CO}_{2}$ collected during the incubation phase. On average, most of the recovered radioactivity $(64 \%, \mathrm{SD} \pm 29)$ was found still remaining in the sediment, while $32 \%$ $(\mathrm{SD} \pm 30)$ was recovered as ${ }^{14} \mathrm{CO}_{2}$ in the traps. A small radioactive fraction was found in the water phase, mainly associated with $\mathrm{DO}^{14} \mathrm{C}(2.3 \%, \mathrm{SD} \pm 1.7)$. On the inner glass walls of the flasks and on plastic trap vials, respectively, $0.14 \%(\mathrm{SD} \pm 0.08)$ and $0.42 \%(\mathrm{SD} \pm 0.88)$ of the total radioactivity was found. The average total amount of ${ }^{14} \mathrm{C}$-pyrene-derived radioactivity recovered from all partial extractions together ranged from 30 to $86 \%$ with an average of $52 \%$ (SD \pm 15 ) of the initially added radioactivity. One replicate from surface sediment exposed to pyrene enriched with Tetraselmis sp. and without fauna was rejected due to methodological and statistical classification as an outlier (Barnett \& Lewis 1984). 


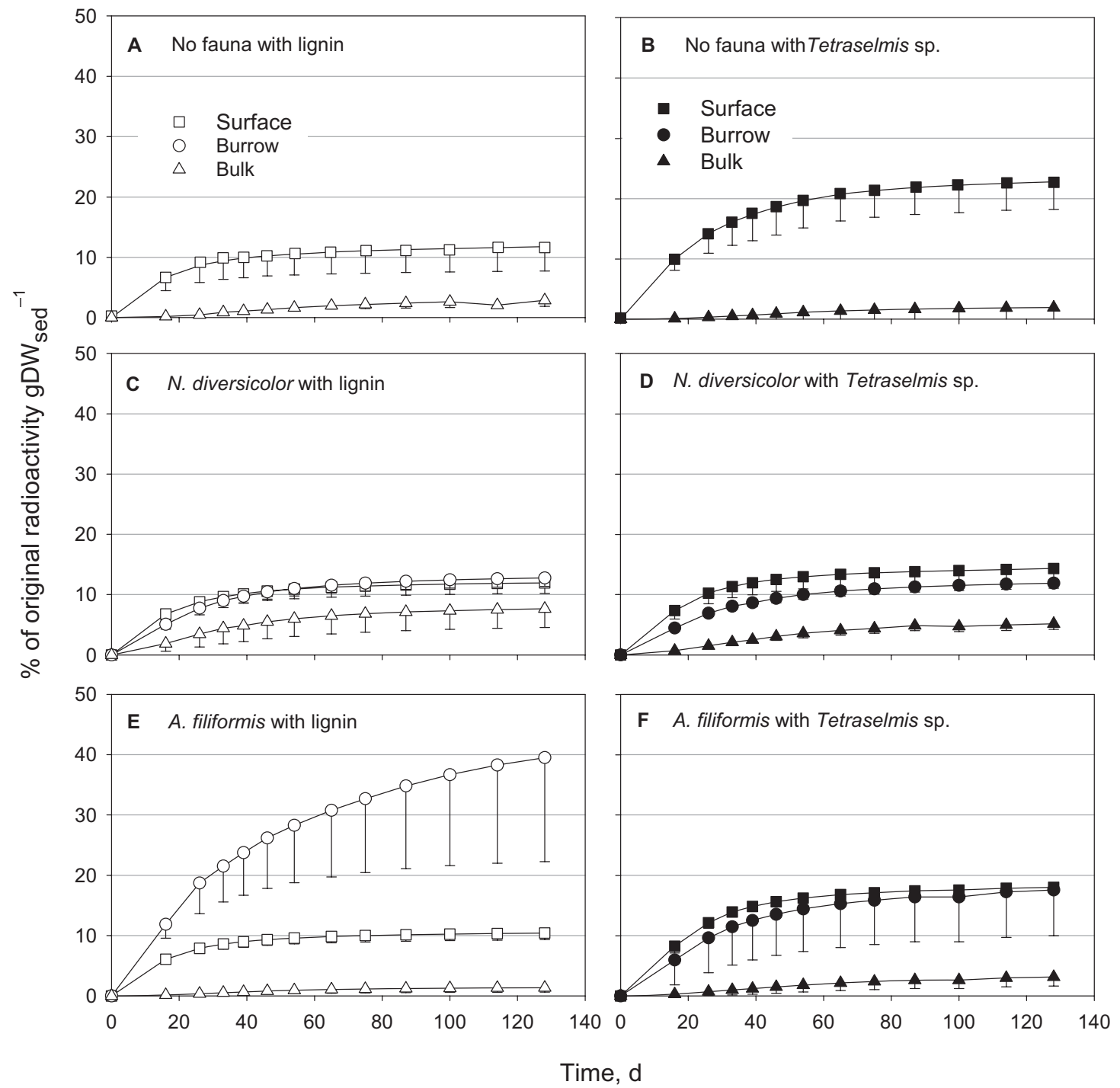

Fig. 4. Cumulative ${ }^{14} \mathrm{C}$-pyrene derived microbial ${ }^{14} \mathrm{CO}_{2}$ production from incubations of pyrene-exposed surface, burrow and bulk sediments. ${ }^{14} \mathrm{CO}_{2}$ production is expressed as $\% \mathrm{~g} \mathrm{DW}_{\text {sed }}{ }^{-1}$, i.e. the isotopic activity of the produced ${ }^{14} \mathrm{C}_{\text {-pyrene-derived }}{ }^{14} \mathrm{CO}_{2}$ divided by the isotopic activity of the ${ }^{14} \mathrm{C}$-pyrene originally added and the amount of sediment ( $\mathrm{g}$ DW) in each incubation flask.

Each point represents 3 replicates and error bars indicate $-\mathrm{SD}$

\section{Trapping efficiency of ${ }^{14} \mathrm{CO}_{2}$}

The retentive effect of sediment on the release of produced ${ }^{14} \mathrm{CO}_{2}$ into the air-filled headspace appeared to increase with the amount of sediment present in the incubation flasks. Extraction/release efficiencies decreased seemingly linearly from $95 \%(\mathrm{SD} \pm 2.5)$ for $0.5 \mathrm{~g}$ DW sediment to $78 \%$ (SD \pm 2.4 ) for $4 \mathrm{~g}$ DW sediment. Linear regression was performed to produce the sediment weight correction formula for ${ }^{14} \mathrm{CO}_{2}$ trap data, $f(x)=-4.95 x+97.4, r^{2}=0.866$, in order to achieve proper comparisons among replicates and treatments. Furthermore, no early breakdown of $\mathrm{NaH}^{14} \mathrm{CO}_{3}$ due to insufficient sterilization procedures was detected.

\section{DISCUSSION}

Exposure to pyrene had a very strong effect, enhancing microbial pyrene-mineralization (MPM) rates in all compartments and treatments, a response which previously has been described for other PAHs in various systems (Bauer \& Capone 1988, Cerniglia 1992, Coates et al. 1996). However, more intriguing was how pyrene exposure generated mineralization patterns, influenced by macrofauna and organic matter quality, which were absent in uncontaminated treatments (Table 4). The strong response in pyrene-exposed treatments likely resulted from a microbial community succession or from the induction of appropriate meta- 
bolic pathways in microbes already present. MPM rates were also higher in sediments with readily available oxygen as illustrated by the successive decrease in mineralization rates from surface and burrow to bulk sediments (Fig. 2). These results are consistent with the established view of microbial PAH degradation being highly favored by the presence of molecular oxygen (Cerniglia \& Heitkamp 1989), and also with results from Chung \& King (1999) and Coates et al. (1996) who found no correlation between PAH mineralization and the availability of other electron acceptors such as nitrate, sulfate and ferric iron in moderately polluted field-collected sediment.

\section{Microbial biodegraders and their requirements}

Ring fission, i.e. the opening of aromatic molecular moieties, is required in order for pyrene and other PAHs to be mineralized, i.e. converted into $\mathrm{CO}_{2}$. Various microbes are capable of performing ring fission, which involves initial incorporation of oxygen into the pollutant molecules facilitated by oxygenase or peroxidase enzymes. The main actors in environmental PAH-mineralization are considered to be certain bacteria which produce prokaryote-specific dioxygenases which efficiently catalyze ring fission, allowing the use of PAHs as their primary carbon source (Cerniglia 1993). Eukaryotes, in general, do not mineralize PAHs, but instead they metabolize these compounds to hydroxylated metabolites by using monooxygenase systems such as the detoxifying cytochrome P450 system (CYP), whereupon metabolites are excreted directly or as conjugates with more polar molecules (Hammel 1995). Nevertheless, some eukaryotes such as the microalgal species Selenastrum capricornutum and fungi belonging to the white-rot family (e.g.

Table 4. Summary of factors significantly affecting microbial pyrene-mineralization (MPM) rates in surface, burrow and bulk sediments derived from 2 -factor ANOVAs with sediment organic matter (SOM) quality (Carbon source) and macrofauna (Fauna) as fixed factors $\left({ }^{*} \mathrm{p}<0.05,{ }^{* *} \mathrm{p}<0.001\right)$. The organic enrichment type or macrofaunal species inducing the highest MPM rate is displayed beneath the significant factor. Indicated in parentheses is the level of the nonsignificant factor with which the significant factor induced the highest MPM rate

\begin{tabular}{|c|c|c|}
\hline $\begin{array}{l}\text { Sediment } \\
\text { compartment }\end{array}$ & Uncontaminated & Pyrene-exposed \\
\hline Surface & No significant effect & $\begin{array}{c}\text { Carbon source } \\
\text { Tetraselmis sp. (no fauna) }\end{array}$ \\
\hline Burrow & $\begin{array}{l}\text { Carbon source* } \\
\text { Tetraselmis sp. }\end{array}$ & $\begin{array}{c}\text { Fauna }^{*} \\
\text { Amphiura filiformis (lignin) }\end{array}$ \\
\hline Bulk & No significant effect & $\begin{array}{c}\text { Fauna }^{*} \\
\text { Nereis diversicolor (lignin) }\end{array}$ \\
\hline
\end{tabular}

Phanerochaete chrysosporium and Pleurotus sp.) are capable of complete PAH mineralization, as they produce prokaryote-like dioxygenases or other unique oxidative enzymes (Bumpus et al. 1985, Hammel 1989, Warshawsky et al. 1995, Wolter et al. 1997). The whiterot fungi are primarily specialized in the degradation of lignins, and ligninolysis involves extra-cellular release of a battery of highly nonspecific, oxidative enzymes such as ligninperoxidase (LIP), manganesedependent peroxidase (MnP) and laccase (Tien \& Kirk 1983). Due to the non-specificity of these enzymes, other lignin-like molecules, such as PAHs, can be attacked and degraded as well (Bumpus et al. 1985, Reddy 1995). Several marine fungi display ligninolytic activity and have been shown to possess lignin-modifying enzymes similar to those of terrestrial white-rot fungi (Raghukumar et al. 1994, Pointing et al. 1998).

Nutrient and substrate availability regulate microbial activity in very specific ways. Bacterial PAH mineralization depends on the relative lability of other carbon sources present, as well as on the versatility of the existing bacterial community. Keyser et al. (1978) reported that the presence of lignin itself does not induce fungal ligninolysis. It is, therefore, reasonable to assume that ligninolysis is not induced by the presence of PAHs either, which is contradictory to the inducible $\mathrm{PAH}$ mineralization observed in bacteria. Microbes require supplementary nutrients for the mineralization of carbon, and nitrogen has in particular been proven vital for efficient bacterial PAH mineralization (ZoBell 1946, Atlas 1981). Nitrogen also plays a pivotal role in the regulation of white-rot fungal metabolism, but in this case, the expression of ligninolytic enzymes is suppressed by nitrogen enrichment and stimulated by nitrogen deficiency (Kirk et al. 1978). By considering the specific nutritional constraints, oxygen requirements and metabolic abilities of different microbes in relation to our experimental exposure conditions, we may interpret the observed MPMs and suggest organisms likely to be responsible for them.

\section{Surface sediment}

Oxygen was always present in the uppermost surface sediment of all treatments (Fig. 5, light-colored surface layer) during the experimental exposure phase, as fresh seawater was continuously provided by the flow through system. In pyrene-exposed surface sediments, enrichment with Tetraselmis sp. resulted in almost a 
Lignin
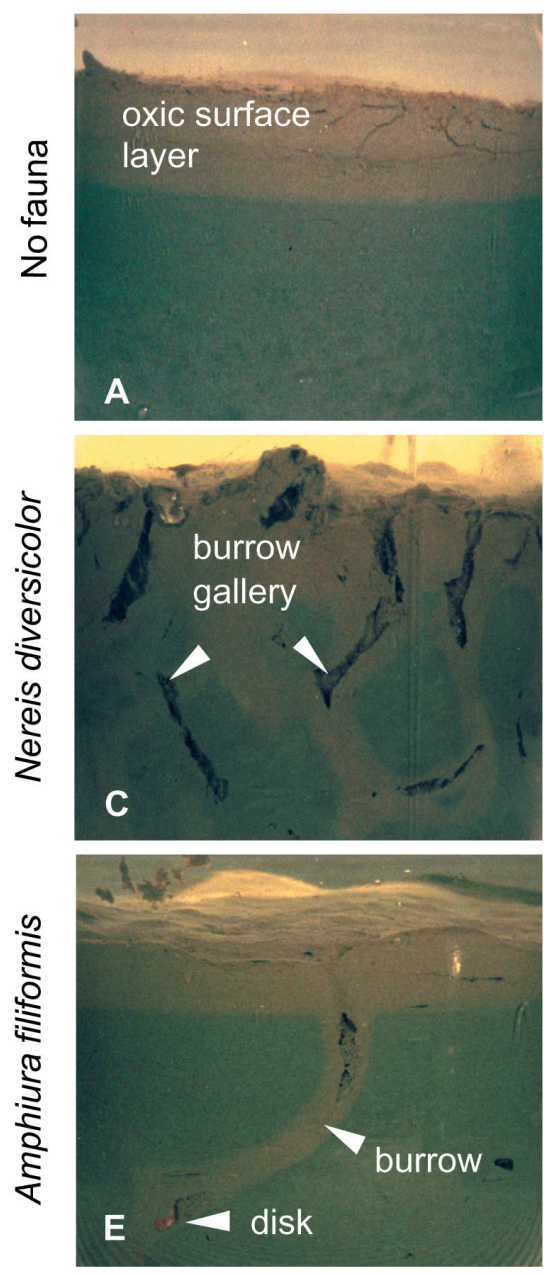

Fig. 5. Sediment images of the different treatments taken at the end of the exposure phase

doubling of the MPM rates compared to enrichment with lignin (Table 3). As mineralization rates increased with the addition of a carbon source high in available nitrogen, bacteria are probably the main pyrene degraders, responding with enhanced pyrene mineralization to the supply of a limiting element (nitrogen). The effect of organic matter quality on MPM rates may also be interpreted in terms of contaminant bioavailability. The fraction of pyrene available for intracellular microbial mineralization may decrease due to a stronger association with refractory organic matter like lignin, compared to labile organic matter like Tetraselmis sp. This theory has been verified by Xing (1997), who measured increased sorption of the 2-ringed PAH naphtalene to soil organic matter as aromaticity increased, i.e. with decreasing SOM quality. Faunal presence further appeared to have suppressed MPM rates in pyrene-exposed surface sediment enriched with Tetraselmis sp. (Fig. 4B,D,F). Subduction of contaminants associated with surface sediment through macrofaunal bioturbation is frequently observed in experimental systems, and has been proposed to hamper the faster aerobic microbial degradation of contaminants (Gilbert et al. 1996, Kure \& Forbes 1997, Hansen et al. 1999). Resuspension, subduction and macrofaunal consumption of pyrene-contaminated organic particles may have resulted in lower exposure concentrations of both pyrene and organic matter in surface sediment with time, where macrofauna was present, thus reducing MPM rates. High SOM quality may further have stimulated surface deposit feeding, which would explain the absence of faunal impact on MPM rates in ligninenriched treatments where the SOM quality was low (Fig. 4A, C,E). The lack of impact of either fauna or organic matter enrichment on MPM rates in uncontaminated surface sediment suggests that most microbes were probably using carbon sources other than pyrene, or that the majority of microbes present were lacking the ability to mineralize polyaromatic compounds. Although not mineralized, degradation of pyrene may still have occurred through the production of CYP metabolites, which were not monitored in this experiment. Association of metabolites with decaying organic matter may further hamper subsequent mineralization of pyrene metabolites, a process reported to be particularly pronounced in microbially-active, previously uncontaminated soils (Guthrie \& Pfaender 1998).

\section{Burrow sediment}

Intriguingly, microbial communities inhabiting sediment from Amphiura filiformis and Nereis diversicolor burrows contributed significantly to the overall biodegradation of sedimentary pyrene. Similar observations have to our knowledge only previously been made by Chung \& King (1999), who measured the microbial degradation potential of various other PAHs in field-collected burrow sediment of 4 marine macroinvertebrates. Selck et al. (2004) do, however, also emphasize the importance of burrows for contaminant degradation, when reporting greater amounts of fluo- 
ranthene metabolites relative to the parent compound in A. filiformis burrow linings compared to surface sediment. It is important to bear in mind that pyrene and organic matter was only added to the surface sediment in our experiment. Consequently, in order for microbes in burrows and deeper parts of the sediment to react to surface conditions, they are entirely dependent on pyrene and organic matter being transferred to them from the surface sediment. Pyrene, with an octanolwater equilibrium partitioning constant $\left(\log \mathrm{K}_{\mathrm{ow}}\right)$ of between 4.50 and 5.32 (Meador et al. 1995) has a high affinity for particles, organic particles in particular, and through adsorption, particles and organic matter become vectors for pyrene transport orchestrated by macrofaunal bioturbation. In the pyrene-exposed treatments, MPM rates were dependent on macrofaunal species, with mineralization rates in $A$. filiformis burrows 1.5 to 2.5 times greater than rates measured in $N$. diversicolor burrows. $N$. diversicolor build large burrow galleries, while $A$. filiformis construct only as much burrow as needed for keeping their bodies buried at ca. $5 \mathrm{~cm}$ depth with 2 to 4 arms protruding from the sediment for feeding (Woodley 1975, Davey 1994). A. filiformis switch between filter and surface deposit feeding, and selected food particles are passed along the arms towards the mouth, generating a continuous downward flux of particles captured in the water and on the sediment surface (Woodley 1975). The brittle star is, thus, adapted for a buried life style only rarely leaving its burrow. $N$. diversicolor are omnivorous polychaetes, sometimes filter feeding within the burrow, and occasionally ascending for epibenthic feeding on everything from living prey to detritus (Fauchald \& Jumars 1979). Even though downward particle transport occurs in sediment inhabited by $N$. diversicolor (Francois et al. 2002), the process is a result of burrowing and moving rather than of an essential feeding act as with $A$. filiformis. A. filiformis has further been shown to concentrate particle reactive contaminants such as fluoranthene and tetrachlorobiphenyl (TCB) in the burrow sediment, with TCB concentrations an order of magnitude higher in burrows compared to the surrounding bulk sediment (Gunnarsson et al. 1999a, Selck et al. 2004). N. diversicolor have been shown to do the same, however, to a lesser extent (Gunnarsson et al. 1999b). The lower TCB concentrations observed in $N$. diversicolor burrows may result from contaminant dilution as the wall surface area of a single $N$. diversicolor burrow is several times larger than that of a single A. filiformis burrow. A similar bioturbation-dependent distribution of pyrene into burrow sediment, resulting in differential pyrene exposure to microbial communities residing within the burrows, may well explain the species-specific differences in MPM rates that we observed in $N$. diversicolor and A. filiformis burrows.
Macrofaunal burrows in both aquatic and terrestrial systems appear to harbor distinct microbial communities, often greater in terms of biomass, diversity or activity, as compared to non-burrow soil and sediment (Dobbs \& Guckert 1988, Tiunov \& Scheu 1999, Bird et al. 2000). Microbial communities collected in marine macrofaunal burrows have also been reported to be highly species-specific (Steward et al. 1996). Further, Chung \& King (2001) discovered 2 previously unidentified marine bacterial species residing in burrow-wall sediment of the polychaete Nereis virens and the mussel Mya arenaria. Both bacterial species were able to use PAHs as their sole carbon source, but with different efficiency. A similar scenario applied to our study provides a plausible explanation for the difference in MPM rates observed in burrow sediments from the 2 macrofaunal species.

The highest MPM rates observed in the entire experiment were measured in pyrene-exposed sediment enriched with lignin from Amphiura filiformis burrows, where rates were almost double compared to enrichments with Tetraselmis sp. and 3.8 times greater than in surface sediment of the same treatment. Oxygen availability in burrows is limited in contrast to surface sediment and therefore, oxygendependent PAH-degrading microbes inhabiting burrows become highly dependent on the intermittent irrigation activity of macrofauna and the reactivity of the SOM. During the experimental exposure phase, enough time was provided for specific redox conditions to develop (Fig. 5). The lability of the SOM affects sedimentary oxygen conditions as labile Tetraselmis sp. is degraded much faster than refractory lignin, thus consuming oxygen at a higher rate than refractory lignin. Visual observations revealed a thin black layer of reduced sediment situated at the interface between bulk and top sediment at ca. $1 \mathrm{~cm}$ depth when enriched with the labile carbon source Tetraselmis sp. in treatments with $A$. filiformis and in controls without macrofauna (Fig. 5B,F). In addition, a large reduced zone appeared associated with the disk chamber in the Tretraselmis sp.-enriched $A$. filiformis treatments (Fig. 5F). The observed redox patterns are supported by measurements by Vopel et al. (2003), who reported a decrease in oxygen saturation with depth in $A$. filiformis burrows, ranging from between 55 and $95 \%$ in arm channels to 40 and $44 \%$ in disk chambers. Disk-associated anoxia may well have been fuelled by a downward transport of labile organic matter (Tetraselmis sp.) from the sediment surface during feeding, as well as by the accumulation of partly digested reactive organic matter in feeding pockets around the disk as a result of the ruminating behavior of $A$. filiformis (M. E. Granberg 
pers. obs.) where food items are repeatedly egested and reingested. Visible anoxia did not appear in any of the organic enrichments with Nereis diversicolor, which evidently succeed in aerating their entire burrow galleries in addition to the subsurface sediment (Fig. 5C,D). Fenchel (1996) measured oxygen saturations ranging between 50 and $80 \%$ in the lumen of small $N$. diversicolor burrows, 0.5 to $1.5 \mathrm{~cm}$ below the sediment surface in field-collected cores. The epibenthic feeding and defecation behavior of $N$. diversicolor should also counteract the subduction of organic matter and subsequent development of burrow sediment and subsurface anoxia. A light oxic coloration of the surface sediment and sediment adjacent to biogenic structures evolved in all treatments. Visible anoxia did not develop in any of the treatments enriched with the refractory carbon source lignin (Fig. 5A,C,E). Consequently, Tetraselmis sp. addition should probably have hampered microbial pyrene mineralization by creating partial oxygen deficiency where oxygen conditions were already strained, as was the case in A. filiformis burrows. Enrichment with Tetraselmis sp. also entails addition of highly available nitrogen. If white-rot fungi were active pyrene degraders in A. filiformis burrows, they probably reacted to the nitrogen addition by switching off their ligninolytic pyrene mineralizing enzyme system. With lignin enrichment, the burrow sediment matrix should successively become diluted with the refractory, nitrogen-poor carbon source, in turn triggering fungal ligninolytic enzyme activity in favor of pyrene mineralization. As opposed to $N$. diversicolor, that displays several different feeding modes, the monotonous subductive feeding behavior of $A$. filiformis should specifically support SOM-mediated differences in microbial pyrene mineralization in the burrows. MPM rates in uncontaminated burrow sediment were controlled by organic matter quality only (Table 4), with the highest rates observed in enrichments with Tetraselmis sp. (Fig. 3B,D). As mineralization rates were comparably low (Table 3), these differences may be of limited ecological significance. Nevertheless, it indicates that microbes in uncontaminated sediment and sediment with previous experience of pyrene contamination differ greatly in metabolic abilities. In uncontaminated sediments, microbial PAH-specialists or metabolic PAH-mineralizing pathways are probably not being induced, yet other microbes and metabolic pathways should be highly active as can be concluded from the development of sedimentary redox patterns (Fig. 5). When uncontaminated sediments eventually encountered pyrene in the incubation flasks, the labile Tetraselmis sp. probably supported both higher available nitrogen levels and greater contaminant bioavailability compared to lignin. This should promote dormant PAH-degrading bacteria or inducible PAH-mineralization pathways to a greater extent.

\section{Bulk sediment}

Microbial pyrene mineralization rates in pyreneexposed bulk sediments were low but measurable, while MPM rates in uncontaminated bulk sediment were almost as low as rates measured in water-only controls. Anaerobic mineralization of PAHs (nitrateand sulfate-reducing conditions) is generally regarded as slow or incomplete compared to aerobic mineralization (Cerniglia 1993, Rockne \& Strand 1998). Complete and highly efficient mineralization of several high and low molecular weight PAHs has, however, recently been observed under strict sulfate-reducing conditions in marine sediment collected from extreme sites with a history of heavy PAH contamination (Coates et al. 1997, Rothermich et al. 2002). Contaminant exposure, thus, also appears critical for microbial mineralization processes in anaerobic environments. As all incubations in our experiment, including those of bulk sediments, were carried out under oxic conditions, the main portion of the registered activity should, however, originate from aerobic microbes, in sediment bearing traces of exposure phase conditions. We, thus, register a 'priming' effect that fauna and organic matter enrichment exerts on oxic microbial pyrene mineralization rather than a true anoxic microbial mineralization in bulk sediment. The significant effect of fauna on bulk sediment MPM rates measured in the pyreneexposed treatments, particularly pronounced with $N$. diversicolor, emphasizes the importance of bioturbation. The extensive burrow system of $N$. diversicolor along with continuous reconstruction and rerouting probably causes higher transport of contaminated oxic surface sediment along with aerobic microbes into anoxic bulk sediment compared to the smaller burrow systems and less vigorous movements of $A$. filiformis. In 2 experiments similar in design, Gunnarsson et al. (1999b) measured elevated TCB concentrations in deeper sediment layers as a result of bioturbation with both $N$. diversicolor and $A$. filiformis. In sediment inhabited by $A$. filiformis, TCB concentrations in burrows were almost an order of magnitude higher than that found in bulk sediment, while TCB concentrations in burrow sediment and bulk sediment were equally high with $N$. diversicolor. Analogously, such bioturbation-dependent distribution of pyrene would lead to elevated exposure concentrations of pyrene along with higher numbers of aerobic pyrene-mineralizing microbes in inhabited reduced bulk sediment, particu- 
larly pronounced with $N$. diversicolor, thus explaining the higher MPM rates we observed in our incubations.

\section{Experimental considerations: flask budget}

When summarizing the extracted radioactivity from all parts of the incubation flask system, the average total recovery was $52 \%(\mathrm{SD} \pm 15 \%)$. The possibility of ${ }^{14} \mathrm{CO}_{2}$ escaping the incubation flasks when released from the sediment is strongly contradicted by the $95 \%$ trapping efficiency obtained when testing the ${ }^{14} \mathrm{CO}_{2}$ incubation systems with $\mathrm{Na}_{2}{ }^{14} \mathrm{CO}_{3}$ as described above. The total recovery values showed no correlation with the MPM rates but were significantly correlated with the sediment radioactivity values (Pearson correlation, $\left.\mathrm{r}^{2}=0.764, \mathrm{p}<<0.001\right)$. Due to the lack of correlation between total recovery and MPM rates, ${ }^{14} \mathrm{CO}_{2}$ values can be safely interpreted. Total recovery values were also shown to be significantly dependent on the quality of the sedimentary organic matter, with lower radioactivity constantly obtained from lignin-enriched systems in both pyrene-exposed (2-way ANOVA $F_{1,30}=35.3$, $\mathrm{p}<0.001$ ) and uncontaminated treatments (2-way ANOVA $\left.F_{1,30}=27.7, \mathrm{p}<0.001\right)$. Most likely, the extraction efficiency of pyrene and metabolites from the sediment is dependent on the SOM quality in that pyrene associates more strongly with the refractory lignin compared to the labile Tetraselmis sp., as has been discussed previously in relation to bioavailability (Xing 1997). However, the most likely explanation for the low total recovery values is related to a methodological problem. At the termination of the incubation phase, the flask sediments were oven-dried at $105^{\circ} \mathrm{C}$. Since pyrene has a melting point of only $150^{\circ} \mathrm{C}$, the drying process may unfortunately have stimulated escape or combustion of the contaminant prior to a radioactive quantification of the sediment, thus giving erroneously low sediment radioactivity values.

\section{CONCLUSIONS}

Along with surface sediment, macrofaunal burrows are to be regarded as important sites for sedimentary pyrene degradation. Macrofauna, thus, actually increase the 'functional surface' of the sediment in terms of PAH degradation through their sedimentary constructions, extending the inter-phase between sediment and water. Yet, burrow-associated PAH mineralization appears to be highly species-specific and also dependent on the trophic state of the system, which complicates a direct translation between burrow and surface sediment function. Consequently, in order not to miscalculate fate and effects of PAHs in marine sediment systems, the present focus on whole sediment or 2-compartment (surface and bulk) models needs to change towards considering biogenic structures as well. Furthermore, as SOM quality and contaminant fate appear so tightly coupled, both geochemically and through organism identity and activity, changes in organic matter input (i.e. due to seasonal phytoplankton blooms or eutrophication) should be taken into account when contaminant fate and effects are assessed in marine systems as a whole.

Acknowledgements. This study was in part supported by grant no. LSF P.44 from the European Commission issued to H.S., by funding within SMP3 issued by the Danish Ministry of the Environment, and by grants kindly donated from Birgit and Birger Wåhlströms memorial fund to M.G. We are grateful to Dr. P. Thor, Dr. K. Magnusson, Prof. R. Rosenberg, Prof. J. Kukkonen, Prof. V. Forbes and anonymous reviewers for helpful comments on earlier drafts. We also thank Dr. J. Gunnarsson for analyzing amino acid contents and G. Clausing and E. Selander for valuable experimental assistance. This is Nereis Park contribution number 9.

\section{LITERATURE CITED}

Aller RC (1988) Benthic fauna and biogeochemical processes in marine sediments: the role of burrow structures. In: Blackburn TH, Sørensen J (eds) Nitrogen cycling in coastal marine environmments. John Wiley \& Sons, New York, p 302-337

Aller RC (1994) Bioturbation and remineralization of sedimentary organic matter: effects of redox oscillation. Chem Geol 114:331-345

Aller RC, Yingst JY (1978) Biogeochemistry of tubedwellings: a study of the sedentary poychaete Amphitrite ornata (Leidy). J Mar Res 36:201-253

Aller RC, Yingst JY (1985) Effects of marine deposit-feeders Heteromastus filiformis (Polychaeta), Macoma balthica (Bivalvia), and Tellina texana (Bivalvia) on averaged sedimentary solute transport, reaction rates, and microbial distributions. J Mar Res 43:615-645

Andersen FØ, Kristensen E (1991) Effects of burrowing macrofauna on organic matter decomposition in coastal marine sediments. Symp Zool Soc Lond 63:69-88

Atlas RM (1981) Microbial degradation of petroleum hydrocarbons: an environmental perspective. Microbiol Rev 45: 180-209

Barnett V, Lewis T (1984) Specific discordancy tests for outliers in univariate samples. In: Outliers in statistical data. John Wiley \& Sons, Norwich, p 167-168

Bauer JE, Capone DG (1985) Degradation and mineralization of the polycyclic aromatic hydrocarbons anthracene and naphtalene in intertidal marine sediments. Appl Environ Microbiol 50:81-90

Bauer JE, Capone DG (1988) Effects of co-occurring aromatic hydrocarbons on degradation of individual polycyclic aromatic hydrocarbons in sediment slurries. Appl Environ Microbiol 54:1649-1655

Bird FL, Boon PI, Nichols PD (2000) Physicochemical and microbial properties of burrows of the deposit-feeding thalassinidean ghost shrimp Biffarius arenosus (Decapoda: Callianassidae). Estuar Coast Shelf Sci 51: 279-291 
Bumpus JA, Tien M, Wright D, Aust SD (1985) Oxidation of persistent environmental pollutants by a white rot fungus. Science 228:1434-1436

Burgess RM, Scott KJ (1992) The significance of in-place contaminated marine sediments on the water column: processes and effects. In: Burton A. G. Jr (ed) Sediment toxicity assessment. Lewis Publishers, Boca Raton, FL, p 129-165

Cerniglia CE (1992) Biodegradation of polycyclic aromatic hydrocarbons. Biodegradation 3:351-368

Cerniglia CE (1993) Biodegradation of polycyclic aromatic hydrocarbons. Curr Opin Biotechnol 4:331-338

Cerniglia CE, Heitkamp MA (1989) Microbial degradation of polycyclic aromatic hydrocarbons (PAH) in the aquatic environment. In: Varanasi U (ed) Metabolism of polycyclic aromatic hydrocarbons in the aquatic environment. CRC press, Boca Raton, FL, p 41-68

Christensen H, Kanneworff E (1985) Sedimenting phytoplankton as major food source for suspension feeders in the Øresund. Ophelia 24:223-244

Christensen H, Kanneworff E (1986) Sedimentation of phytoplankton during a spring bloom in the Øresund. Ophelia 26:109-122

Chung WK, King GM (1999) Biogeochemical transformations and potential polyaromatic hydrocarbon degradation in macrofaunal burrow sediments. Aquat Microb Ecol 19: 285-295

Chung WK, King GM (2001) Isolation, characterization, and polyaromatic hydrocarbon degradation potential of aerobic bacteria from marine macrofaunal burrow sediments and description of Lutibacterium anuloederans gen. nov., sp nov., and Cycloclasticus spirillensus sp nov. Appl Environ Microbiol 67:5585-5592

Coates JD, Anderson RT, Lovley DR (1996) Oxidation of polycyclic aromatic hydrocarbons under sulfate-reducing conditions. Appl Environ Microbiol 62:1099-1101

Coates JD, Woodward J, Allen J, Philp P, Lovley DR (1997) Anaerobic degradation of polycyclic aromatic hydrocarbons and alkanes in petroleum-contaminated marine harbor sediments. Appl Environ Microbiol 63:3589-3593

Davey JT (1994) The architecture of the burrow of Nereis diversicolor and its quantification in relation to sedimentwater exchange. J Exp Mar Biol Ecol 179:115-129

Dobbs FC, Guckert JB (1988) Callianassa trilobata (Crustacea, Thalassinidea) influences abundance of meiofauna and biomass, composition, and physiologic state of microbial communities within its burrow. Mar Ecol Prog Ser 45: 69-79

Fauchald K, Jumars P (1979) The diet of worms; a study of polychaete feeding guilds. Oceanogr Mar Biol Annu Rev 17:193-284

Fenchel T (1996) Worm burrows and oxic microniches in marine sediments. 1. Spatial and temporal scales. Mar Biol 127:289-295

Forster S (1996) Spatial and temporal distribution of oxidation events occurring below the sediment-water interface. PSZN I: Mar Ecol 17:309-319

Francois F, Gerino M, Stora G, Durbec JP, Poggiale JC (2002) Functional approach to sediment reworking by galleryforming macrobenthic organisms: modeling and application with the polychaete Nereis diversicolor. Mar Ecol Prog Ser 229:127-136

Gardner WS, Lee RF, Tenore KR, Smith LW (1979) Degradation of selected polycyclic aromatic hydrocarbons in coastal sediments: importance of microbes and polychaete worms. Water Air Soil Pollut 11:339-347

Gilbert F, Stora G, Bertrand JC (1996) In situ bioturbation and hydrocarbon fate in an experimental contaminated Mediterranean coastal ecosystem. Chemosphere 33:1449-1458

Graf G (1992) Benthic-pelagic coupling: a benthic view. Oceanogr Mar Biol Annu Rev 30:149-190

Graf G, Schulz R, Peinert R, Meyer-Reil LA (1983) Benthic response to sedimentation events during autumn to spring at a shallow-water station in the Western Kiel Bight I. Analysis of processes on a community level. Mar Biol 77: 235-246

Grémare A, Amouroux JM, Charles F, Dinet A and 7 others (1997) Temporal changes in the biochemical composition and nutritional value of the particulate organic matter available to surface deposit-feeders: a two year study. Mar Ecol Prog Ser 150:195-206

Gunnarsson JS, Granberg ME, Nilsson HC, Rosenberg R, Hellman B (1999a) Influence of sediment-organic matter quality on growth and polychlorobiphenyl bioavailability in Echinodermata (Amphiura filiformis). Environ Toxicol Chem 18:1534-1543

Gunnarsson JS, Hollertz K, Rosenberg R (1999b) Effects of organic enrichment and burrowing activity of the polychaete Nereis diversicolor on the fate of tetrachlorobiphenyl in marine sediments. Environ Toxicol Chem 18: 1149-1156

Guthrie EA, Pfaender FK (1998) Reduced pyrene bioavailability in microbially active soils. Environ Sci Technol 32: 501-508

Hammel KE (1989) Organopollutant degradation by ligninolytic fungi. Enzyme Microb Technol 11:776-777

Hammel KE (1995) Organopollutant degradation by ligninolytic fungi. In: Young LY, Cerniglia CE (eds) Mechanisms of polycyclic aromatic hydrocarbon degradation. Wiley-Liss, New York, p 331-346

Hansen R, Forbes TL, Westermann P (1999) Inportance of bioturbation and feeding by the polychaete Capitella sp. 1 in the degradation of di(2-ethylhexyl)phthalate (DEHP). Mar Ecol Prog Ser 182:187-199

Hedges JI, Stern JH (1984) Carbon and nitrogen determinations of carbonate-containing solids. Limnol Oceanogr 29: 657-663

HELCOM (1996) Third periodic assessment of the state of the environment of the Baltic Sea, 1989-1993. Report No. 64B, HELCOM, Helsinki

Holmer M, Forbes VE, Forbes TL (1997) Impact of the polychaete Capitella sp. I on microbial activity in an organic-rich marine sediment contaminated with the polycyclic aromatic hydrocarbon fluoranthene. Mar Biol 128:679-688

Hulthe G, Hulth S, Hall POJ (1998) Effect of oxygen on degradation rate of refractory and labile organic matter in continental margin sediments. Geochim Cosmochim Acta 62: 1319-1328

Jerina DM, Daly JW (1974) Arene oxides: a new aspect of drug metabolism. Science 185:573-582

Jonasson A, Olausson E (1966) New devices for sediment sampling. Mar Geol 4:365-372

Keyser P, Kirk TK, Zeikus JG (1978) Ligninolytic enzyme system of Phanerochaete chrysosporium: synthesized in the absence of lignin in response to nitrogen starvation. J Bacteriol 135:790-797

Kirk TK, Schultz E, Connors WJ, Lorenz LF, Zeikus JG (1978) Influence of culture parameters on lignin metabolism by Phanerochaete chrysosporium. Arch Microbiol 117: 277-285

Kristensen E (2000) Organic matter diagenesis at the oxic/anoxic interface in coastal marine sediments, with emphasis on the role of burrowing animals. Hydrobiologia 426:1-24 
Kristensen E, Blackburn TH (1987) The fate of carbon and nitrogen in experimental marine sediment systems: influence of bioturbation and anoxia. J Mar Res 45: 231-257

Kure LK, Forbes TL (1997) Impact of bioturbation by Arenicola marina on the fate of particle-bound fluoranthene. Mar Ecol Prog Ser 156:157-166

Landrum PF, Robbins JA (1990) Bioavailability of sedimentassociated contaminants to benthic invertebrates. In: Baudo R, Giesy JP, Muntau H (eds) Sediments: chemistry and toxicity of in-place pollutants. Lewis publishers, Ann Arbor, MI, p 237-263

Lee H II, Swartz RC (1980) Biological processes affecting the distribution of pollutants in marine sediments. Part II. Biodeposition and bioturbation. In: Barker RA (ed) Contaminants and sediments, Vol 2. Ann Arbor Science Publishers, Ann Arbor, MI, p 555-606

Lueking AD, Huang WL, Soderstrom-Schwarz S, Kim MS, Weber WJ (2000) Relationship of soil organic matter characteristics to organic contaminant sequestration and bioavailability. J Environ Qual 29:317-323

Mayer LM, Schick LL, Sawyer T, Plante CJ, Jumars PA, Self RL (1995) Bioavailable amino acids in sediments: a biomimetic, kinetics-based approach. Limnol Oceanogr 40: 511-520

McElroy AE, Farrington JW, Teal JM (1989) Bioavailability of polycyclic aromatic hydrocarbons in the aquatic environment. In: Varanasi U (ed) Metabolism of polycyclic aromatic hydrocarbons in the aquatic environment. CRC Press, Boca Raton, FL, p 1-39

Meador JP, Stein JE, Reichert WL, Varanasi U (1995) Bioaccumulation of polycyclic aromatic hydrocarbons by marine organisms. Rev Environ Contam Toxicol 143:79-165

Neff JM (2002) Polycyclic aromatic hydrocarbons in the ocean. In: Bioaccumulation in marine organisms, effect of contaminants from oil well produced water. Elsevier Science, Oxford, p 241-318

OSPAR-Commission (2000) Quality status report 2000, OSPAR Commission, London

Pointing SB, Vrijmoed LLP, Jones EBG (1998) A qualitative assessment of ligninocellulose degrading enzyme activity in marine fungi. Bot Mar 41:293-298

Raghukumar C, Raghukumar S, Chinnaraj A, Chandramohan D, D'Souza TM, Reddy CA (1994) Laccase and other igninocellulose modifying enzymes of marine fungi isolated from the coast of India. Bot Mar 37:515-523

Reddy CA (1995) The potential for white-rot fungi in the treatment of pollutants. Curr Opin Biotechnol 6:320-328

Reid BJ, MacLeod CJA, Lee PH, Morriss AWJ, Stokes JD, Semple KT (2001) A simple 14C-respirometric method for assessing microbial catabolic potential and contaminant bioavailability. FEMS Microbiol Lett 196:141-146

Editorial responsibility: John Gray (Contributing Editor), Oslo, Norway
Rockne KJ, Strand SE (1998) Biodegradation of bicyclic and polycyclic aromatic hydrocarbons in anaerobic enrichments. Environ Sci Technol 32:3962-3967

Rothermich MM, Hayes LA, Lovley DR (2002) Anaerobic, sulfate-dependent degradation of polycyclic aromatic hydrocarbons in petroleum-contaminated harbor sediment. Environ Sci Technol 36:4811-4817

Selck H, Granberg ME, Forbes VE (2004) Impact of sediment organic matter quality on fate and effects of fluoranthene in the infaunal brittle star Amphiura filiformis. Mar Environ Res 59:19-46

Smetacek V (1980) Annual cycle of sedimentation in relation to plankton ecology in Western Kiel Bight. Ophelia 1:65-76

Steward CC, Nold SC, Ringelberg DB, White DC, Lovell CR (1996) Microbial biomass and community structures in the burrows of bromophenol producing and non-producing marine worms and surrounding sediments. Mar Ecol Prog Ser 133:149-165

Tenore KR (1977) Growth of Capitella capitata cultured on various levels of detritus derived from different sources. Limnol Oceanogr 22:936-941

Tenore KR, Cammen L, Findlay SEG, Phillips N (1982) Perspectives of research on detritus: do factors controlling the availability of detritus to microconsumers depend on its source? J Mar Res 40:473-490

Tien M, Kirk TK (1983) Lignin-degrading enzyme from the hymenomycete Phanerochaete chrysosporium Burds. Science 221:661-663

Tiunov AV, Scheu S (1999) Microbial respiration, biomass, biovolume and nutrient status in burrow walls of Lumbricus terrestris L. (Lumbricidae). Soil Biol Biochem 31: 2039-2048

Vopel K, Thistle D, Rosenberg R (2003) Effect of the brittlestar Amphiura filiformis (Amphiuridae, Echinodermata) on oxygen flux into the sediment. Limnol Oceanogr 48: $2034-2045$

Warshawsky D, Cody T, Radike M, Reilman R, Schumann B, Ladow K, Schneider J (1995) Biotransformation of benzo(a)pyrene and other polycyclic aromatic hydrocarbons and heterocyclic analogs by several green algae and other algal species under gold and white light. Chem-Biol Interact 97:131-148

Wolter M, Zadrazil F, Martens R, Bahadir M (1997) Degradation of eight highly condensed polycyclic aromatic hydrocarbons by Pleurotus sp. Florida in solid wheat straw substrate. Appl Microbiol Biotechnol 48:398-404

Woodley JD (1975) The behaviour of some amphiurid brittlestars. J Exp Mar Biol Ecol 18:29-46

Xing B (1997) The effect of the quality of soil organic matter on sorption of naphtalene. Chemosphere 35:633-642

ZoBell CE (1946) Action of microorganisms on hydrocarbons. Bacteriol Rev 10:1-49

Submitted: October 20, 2003; Accepted: September 21, 2004 Proofs received from author(s): February 10, 2005 